\title{
IMPACT OF GLOBULINS DERIVED FROM GENETICALLY MODIFIED AND CONVENTIONAL SOYBEAN ON SWINE LYMPHOCYTE PROLIFERATION IN IN VITRO CULTURES
}

\author{
Mariola Galbas ${ }^{1}$, Kamila Borys ${ }^{1}$, Anna Woźniak ${ }^{2}$, Marek Selwet ${ }^{3}$ \\ ${ }^{1}$ Department of Biochemistry and Biotechnology, Poznan University of Life Sciences, \\ Wołyńska 35, 60-637 Poznań, Poland \\ ${ }^{2}$ Institute of Human Genetics, Polish Academy of Sciences, \\ Strzeszyńska 32, 60-479 Poznań, Poland \\ ${ }^{3}$ Department of General and Environmental Microbiology, Poznan University of Life Sciences, \\ Szydłowska 50, 60-656 Poznań, Poland \\ Corresponding author: mariolagalbas@gmail.com
}

\begin{abstract}
The majority of the global feed market is dominated by the Roundup Ready 40-3-2 transgenic soybean varieties developed and marketed by Monsanto Company, which are characterized by tolerance to glyphosate, the active ingredient of the Roundup herbicide. It should be remembered, however, that soybean is one of the major allergens which may affect animal health. The aim of the study was to compare allergenic properties of globulins derived from genetically modified (GM) soybean imported from the USA and conventional soybean developed in Poland. Analyses were performed by measuring porcine lymphocyte proliferation in in vitro cultures. It turned out that both genetically modified and conventional soybean proteins caused immune response at the level of negative control. A slight increase in relation to the negative control was observed in the case of 7S and 11S fractions derived from the GM meal and 7S fraction isolated from Nawiko meal.
\end{abstract}

Key words: GMO, soybean proteins, in vitro, proliferation, phytohaemagglutinin (PHA)

Soybean is among the most valuable crop plants cultivated in the world. It occupies the first place among leguminous plants in the world trade and, due to its exceptionally advantageous grain chemical composition, it finds wide application in industry, agriculture and household (Hryncewicz, 1992). Seeds of soybean contain proteins and lipids - the most important constituents from the industrial point of view - as well as carbohydrates, enzymes and antinutritional substances. In feeding experiments in which crude and processed soybean seeds were given to rats (Baranowski et al., 2006), chickens (Świątkiewicz et al., 2008, 2010) and pigs (Cromwell et al., 2002), no significant differences were observed in comparison with the unmodi- 
fied A5403 soybean line. The content of nutritional constituents such as protein, fat, fibre, ash, carbohydrates, amino acids and fatty acids in the modified soybean was the same as in the conventional counterpart. In addition, the composition of antinutritional substances - trypsin inhibitors and lectins - also failed to show differences in relation to classical soybean (Padgette et al., 1996; Song et al., 2008). Soybean reserve proteins include albumins and globulins. Soybean seeds contain approximately $90 \%$ globulins and $10 \%$ albumins. Due to sedimentation properties of soybean proteins, the following fractions can be distinguished in a standard saccharose gradient of $7.6 \mathrm{pH}$ and 0.5 ionic strength: 2S, 7S, 11S and 15S (Hill and Breidenbach, 1974; Berk, 1992; Laszlo, 1998). Fraction 7S constitutes 34\% of all fractions and it is a very heterogeneous fraction whose principal component is conglycinin, which makes up about $30 \%$ of soybean reserve proteins. Apart from conglycinin, the fraction also comprises numerous enzymes, among others amylase, lipoxygenase and urease as well as haemagglutinins. It is in this fraction that the main soybean allergen Gly m Bd 30 K occurs (Berk, 1992; Holzhauser et al., 2009). The 11S fraction constitutes $40 \%$ of the reserve proteins of soybean seed. Furthermore, soybean contains globular proteins which are responsible for the occurrence of allergies (Tsuji et al., 2001; Wróblewska, 2002; Szymkiewicz, 2007; Jędrusek-Golińska et al., 2010). Water-soluble proteins are considered to be the most allergenic. They include Gly $\mathrm{m} \mathrm{Bd}$ $30 \mathrm{~K}$, reserve proteins, glycinin and $\beta$-conglycinin as well as profilin Gly $\mathrm{m} 3$. On the other hand, Gly m 1, Gly m 2 as well as Kunitz inhibitor are responsible for hypersensitivity reactions of the respiratory system (Besler et al., 2000). Soybean meal provides $70 \%$ of high protein materials used to manufacture feed mixtures. A huge majority of soybean grain is used to produce animal feeds, primarily soybean meal and other special soybean products (Tsuji et al., 2001). Bearing in mind the widespread application of soybean meal and its products in swine nutrition (Świątkiewicz et al., 2011), attention was paid to its impact on evoking hypersensitivity in pigs and to the effect of this phenomenon on their body weight gains and intestine morphology. The majority of antinutritional substances contained in soybean undergo deactivation in the course of technical processing, although such treatment fails to reduce the levels of antigen proteins (Lipiński, 1999). Piglets fed diets containing soybean meal exhibited a lower growth index and height of intestinal villi and a higher content of IgG antibodies in blood. Moreover, when piglets were fed a concentrate of soybean meal protein, their daily weight gain index was lower in comparison with the control, yet higher when compared with the animals fed soybean meal. Soybean meal from GM soybean is, in fact, an equivalent of soybean meal derived from genetically unmodified soybean both with regard to its composition and proportions of nutritional and antinutritional components (Padgette et al., 1996; Cromwell et al., 2002).

In Poland, soybean is cultivated on a small scale and the majority of this product is imported in processed form, e.g. as soybean meal. Following negotiations with the European Union, Poland agreed to harmonize the feeding regulations with those of the EU. The formal change of the Feed Bill postponing the ban on the commercial traffic of GM products until 31 December 2012 was adopted in the parliamentary act of 26 June 2008. 
The aim of the present investigations was to obtain homogenous 7S and 11S fractions of soybean proteins (including those derived from GM and non-GM soybean) and to analyse their impact on swine lymphocyte proliferation in in vitro cultures.

\section{Material and methods}

Seeds and meal of conventional soybean cv. Nawiko were obtained from the Department of Plant Genetics and Breeding of the University of Life Sciences in Poznań (Nawracała, 2000). Genetically modified soybean meal, protein concentrate of GM soybean (Roundup Ready 40-3-2), and protein concentrate of genetically unmodified soybean 'VITKON' (manufactured and distributed by Vitpol) were obtained from the Wielkopolska Centre for the Quality of Agri-Food Products.

The animal material used in the experiment was porcine blood collected from 6 -month-old pigs of the Złotnicka White breed $(n=6)$. Defatted soybean flour was prepared in accordance with the procedure proposed by Liu et al. (2007). Seeds were either dehulled mechanically or left intact. The prepared material was ground in a grinder. The flour obtained was extracted using n-hexane at 1:5 ratio for the period of 1 hour at room temperature and then centrifuged at $4000 \mathrm{rpm}$ for 15 minutes at $4{ }^{\circ} \mathrm{C}$. The supernatant was discarded. The extraction was repeated twice. The collected precipitate constituted defatted soybean flour. Soybean meal was prepared on the basis of the Laszlo (1988) method. Grains were rinsed several times, dried, dehulled mechanically and ground in a grinder. The ground material was heated up to the temperature of $73.4^{\circ} \mathrm{C}$ in order to soften it prior to extraction. The extraction was conducted using $n$-hexane for the period of 1 hour at room temperature and then centrifuged at $4000 \mathrm{rpm}$ for 15 minutes at $4^{\circ} \mathrm{C}$. The meal was then toasted for 15 minutes in water vapour at $100^{\circ} \mathrm{C}$ and dried. Protein isolation was carried out in accordance with the methodology developed by Liu et al. (2007) and modified for the needs of further experiments. Protein concentrations were measured with the assistance of a NanoDrop spectrophotometer. Electrophoresis was performed in the presence of SDS (12\% polyacrylamide gel). Gels were stained in Coomassie Brilliant Blue. Purification of the isolated proteins was carried out using the method of gel filtration on Sepharose CL 6B balanced with $0.03 \mathrm{M}$ Tris - $\mathrm{HCl}$ buffer, $\mathrm{pH}$ 8.0, $0.7 \mathrm{M} \mathrm{NaCl}$ and 0.01 M DTT (Thanh et al., 1975). Lymphocyte isolation was performed in accordance with the standard method using gradisol modified at the Department of Biology and Environmental Protection of Poznań Medical University. Cell observations were conducted under a light microscope at 10x magnification. The number of lymphocytes was determined after staining with Türk's solution in a Bürker chamber. Using the lymphocytes obtained, $100 \mu$ l cultures were established on 96-well microtitre plates adding $100 \mu \mathrm{l}$ solution of the examined proteins in order to obtain the final culture concentration: $10 \mu \mathrm{g} / \mathrm{ml}$ proteins, $10 \%$ NOS and $1 \%$ antibiotic. The negative control was pure medium without protein addition. The positive control was a lymphocyte culture stimulated with phytohaemagglutinin (PHA) of $5 \mu \mathrm{l} / \mathrm{ml}$ concentration. The culture prepared as described above was incubated at $37^{\circ} \mathrm{C}$ for 74 hours in $5 \% \mathrm{CO}_{2}$ atmosphere and then, using BrdU Cell Proliferation 
Assay (CHEMICON® International, Serologicals Company), lymphocyte proliferation was assessed.

Statistical analysis was performed in accordance with the GLM procedure of the SAS program (1999) employing Tukey's test.

\section{Results}

The crude protein extracts as well as proteins after separation were evaluated on $12 \%$ polyacrylamide gel with SDS in accordance with their isoelectric point (Figures 1-3).

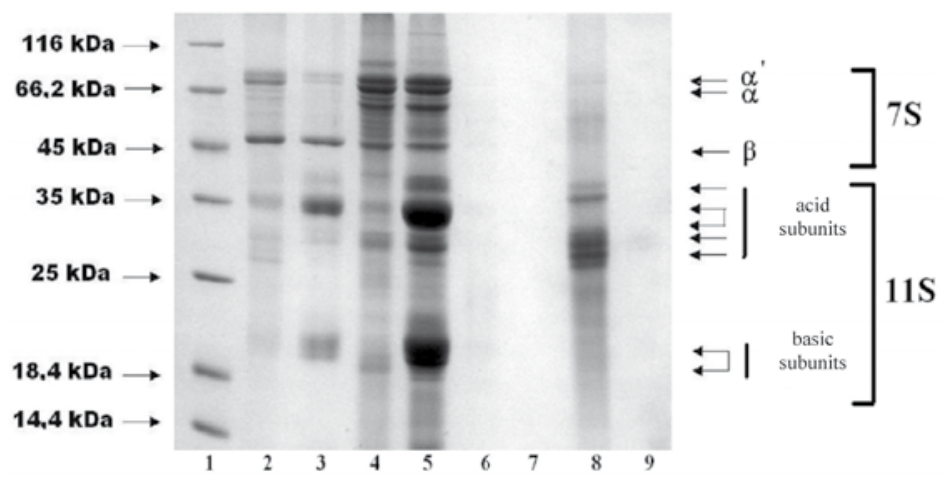

Figure 1. Electrophoretic picture of soybean fractions isolated in accordance with their isoelectric point (after fractionation). Lane 1 - size marker lane, 2 - non-hulled Nawiko soybean; lane 3 - non-hulled Nawiko soybean, fraction 11S; lane 4 - fraction 7S; lane 5 - GM soybean, fraction $11 \mathrm{~S}$; lane 6 protein concentrate 'VITKON' GM, fraction 7S; lane 7 - protein concentrate 'VITKON' GM, fraction 11S; lane 8 - protein concentrate 'VITKON' non-GM, fraction 7S; lane 9 - protein concentrate 'VITKON' non-GM, fraction 11S

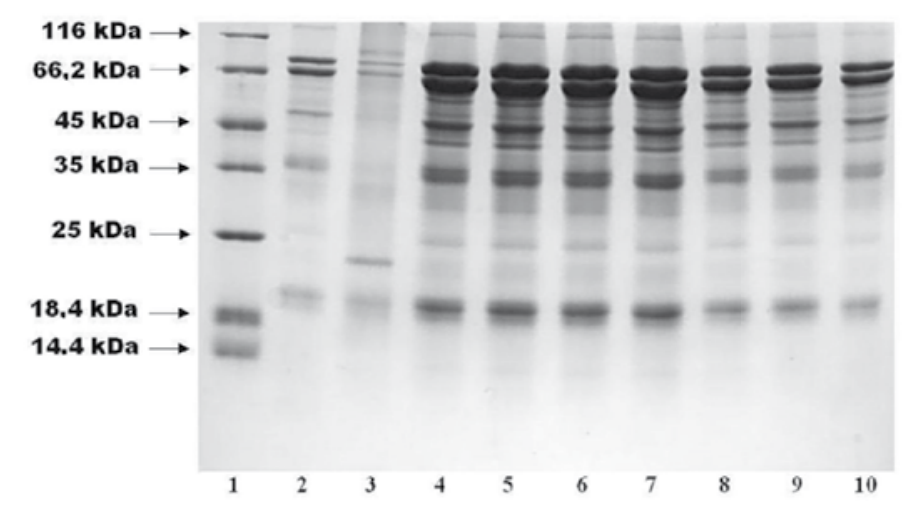

Figure 2. Electrophoretic picture of soybean fractions obtained following gel filtration on Sepharose CL $6 \mathrm{~B}$ of Nawiko meal, fraction 7S. Lane 1 - size marker; lane 2 - initial sample placed on the column; lanes 3-10 - selected fractions 


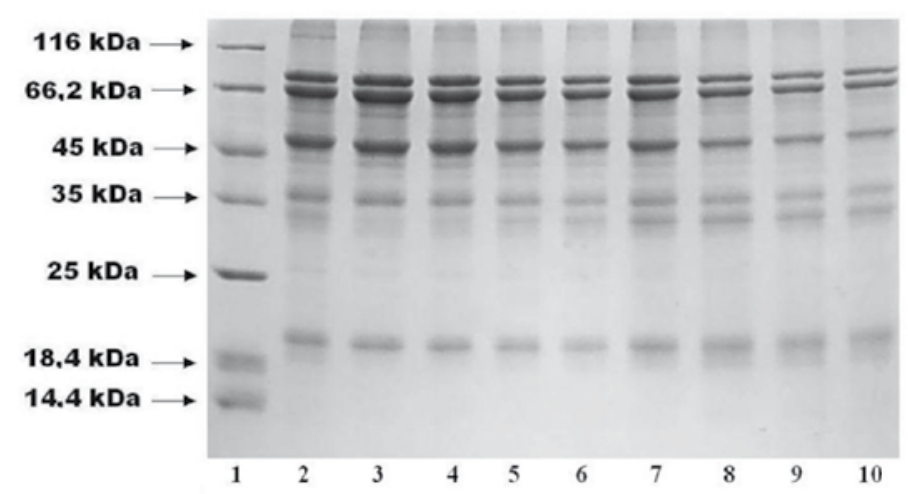

Figure 3. Electrophoretic picture of soybean fractions obtained following gel filtration on Sepharose CL 6B of GM soybean. Lane 1 - size marker; lane 2 - initial sample placed on the column; lanes 3-10 - selected fractions

Following fractionation, 7S and 11S fractions were obtained which were evaluated in $12 \%$ polyacrylamide gel. Individual fractions were purified further on Sepharose $\mathrm{CL} 6 \mathrm{~B}$ and the protein fractions obtained were subjected to quality assessment in $12 \%$ polyacrylamide gel.

All fractions selected for tests on lymphocyte proliferation were dialysed against $0.03 \mathrm{M}$ Tris- $\mathrm{HCl}, \mathrm{pH} 7.5$ buffer.

The following samples were used to test swine lymphocyte proliferation: crude extracts of non-hulled and hulled Nawiko soybean grain, Nawiko meal, GM meal, GM and non-GM protein concentrates as well as samples of non-hulled 7S fraction Nawiko soybean, hulled 7S fraction Nawiko, Nawiko meal fractions 7S and 11S subjected to molecular filtration and samples of 11S fractions of GM and non-GM protein concentrates not subjected to molecular filtration. In the case of GM and nonGM meal, both 7S and 11S fractions were selected, bearing in mind that soybean meal is widely used as swine feed. Crude soybean seeds are not used so commonly in animal feeding because they contain antinutritional substances, of which Kunitz trypsin inhibitor is the most important.

In order to estimate the degree of swine lymphocyte proliferation in the in vitro cultures, alongside tests on the examined samples, both negative (clean medium, without mitogens) and positive controls (with phytohaemagglutinin) were carried out for each blood sample. The ratio of absorbance at $450 \mathrm{~nm} / 550 \mathrm{~nm}$ wavelengths in the examined protein samples was measured on an ELISA reader (Table 1). 
Table 1. Ratio of absorbance $(450 \mathrm{~nm} / 550 \mathrm{~nm})$ of the examined protein samples at a concentration of $10 \mu \mathrm{g} \mathrm{ml}^{-1}$

\begin{tabular}{l|c|c|c|c|c|c|c}
\hline \multirow{2}{*}{ Raw material type } & \multicolumn{7}{c}{ Samples of blood $(\mathrm{n}=6)$} \\
\cline { 2 - 8 } & 1 & 2 & 3 & 4 & 5 & 6 & Mean \\
\hline Negative control & 4.23 & 2.68 & 3.33 & 3.46 & 1.74 & 2.76 & $3.03 \mathrm{a}$ \\
$\begin{array}{l}\text { Positive control } \\
\text { PHA 10 } \mu \mathrm{g} \mathrm{m}^{-1}\end{array}$ & 5.55 & 2.96 & 3.71 & 6.06 & 1.67 & 3.03 & $3.83 \mathrm{~b}$ \\
$\begin{array}{l}\text { Crude extract } \\
\text { Nawiko meal }\end{array}$ & 5.10 & 3.21 & 3.59 & 2.38 & 1.67 & 3.22 & $3.20 \mathrm{a}$ \\
$\begin{array}{l}\text { Crude extract } \\
\text { GMO soybean }\end{array}$ & 6.70 & 2.59 & 2.82 & 2.33 & 1.52 & 2.65 & $3.10 \mathrm{a}$ \\
$\begin{array}{l}\text { Nawiko meal } \\
\text { fraction 7S }\end{array}$ & 10.03 & 3.70 & 3.86 & 3.53 & 1.65 & 3.63 & $4.40 \mathrm{c}$ \\
$\begin{array}{l}\text { Nawiko meal } \\
\text { fraction 11S }\end{array}$ & 4.90 & 2.97 & 3.43 & 3.30 & 1.84 & 2.89 & $3.22 \mathrm{a}$ \\
$\begin{array}{l}\text { GM meal } \\
\text { fraction 7S }\end{array}$ & 6.81 & 3.29 & 3.53 & 3.70 & 1.67 & 3.12 & $3.69 \mathrm{~b}$ \\
$\begin{array}{l}\text { GM meal } \\
\text { fraction 11S }\end{array}$ & 3.73 & 3.33 & 3.73 & 4.35 & 1.66 & 3.26 & $3.34 \mathrm{a}$ \\
$\begin{array}{l}\text { Protein concentrate } \\
\text { non-GM } \\
\text { fraction 11S }\end{array}$ & 5.66 & 3.04 & 3.38 & 3.78 & 1.85 & 3.06 & $3.46 \mathrm{a}$ \\
$\begin{array}{l}\text { Protein concentrate } \\
\text { GM } \\
\text { fraction 11S }\end{array}$ & 4.97 & 2.88 & 3.45 & 2.45 & 1.86 & 2.87 & $3.08 \mathrm{a}$ \\
\hline
\end{tabular}

a, b, c - means designated with identical letters in the column do not differ significantly at $\mathrm{P}<0.01$.

\section{Discussion}

Soybean meal as well as protein concentrates provide the main source of amino acids used in swine nutrition and, at the same time, soybean proteins are mentioned as one of the main eight feed allergens. Appropriate swine diets translate into animal health as well as the level and quality of body weight gains. At present, soybean meal, most frequently genetically modified, is imported and domestic production of this important feed component practically does not exist. Nevertheless, there are Polish soybean cultivars such as Nawiko, developed by the Department of Plant Genetics and Breeding of the Poznan University of Life Sciences which have never been investigated for their possible antigenic properties. This study makes an attempt to compare the impact of different soybean materials - conventional soybean seeds, soybean meal prepared from these seeds for purposes of this experiment, GM soybean meal as well as soybean protein concentrates (both from GM and non-GM soybean seeds) on swine lymphocyte proliferation in in vitro cultures. The aim of the trial was to investigate the influence of $7 \mathrm{~S}$ and $11 \mathrm{~S}$ soybean fractions considered as the most allergenic on swine lymphocyte proliferation in 
in vitro cultures. The image of crude extracts (Figure 1) obtained using the method elaborated by Liu et al. (2007) shows differences and similarities between the examined samples. Stripes representing crude extracts obtained from hulled and non-hulled seeds of Nawiko soybean fail to show significant differences in the amount of bands and their intensity. These results indicate a negligible quantity of proteins found in the hull in comparison with the amount of reserve proteins derived from cotyledons. Comparison of the images of Nawiko soybean meal with images obtained for hulled and non-hulled seeds of the same variety reveals a difference in the presence of protein of about $23 \mathrm{kDa}$ mass as well as protein of $78 \mathrm{kDa}$ mass. These proteins are missing in the electrophoretic picture of the meal. There is also a difference in the amount of $20 \mathrm{kDa}$ protein. The above results confirm changes in the quantity and quality of proteins following toasting of crude seeds and these differences can affect antigen properties. Electrophoretic pictures of conventional and genetically modified meals are similar. Nevertheless, there is a difference between the two materials with regard to the amount of $48 \mathrm{kDa}$ protein. An unexpected picture emerged from protein concentrates, both genetically modified and non-modified. Acid subunits of fraction $11 \mathrm{~S}$ appeared in the place where subunits of the $7 \mathrm{~S}$ fraction were expected. In the case of the lane representing fraction $11 \mathrm{~S}$, in both cases, subunits of both fractions were obtained with a quantitative advantage of fraction 11S subunits and numerous low-molecular polypeptides. This proves that proteins (primarily of $7 \mathrm{~S}$ fraction) undergo degradation during the process of concentrate manufacture. The method of gel filtration on Sepharose CL 6B was considered sufficient for additional purification of individual fractions from small quantities of impurities as well as for the removal of protein aggregates. From the performed proliferation tests it can be concluded with a considerable degree of probability that the $7 \mathrm{~S}$ fraction of the Nawiko meal as well as $7 \mathrm{~S}$ and $11 \mathrm{~S}$ fractions of the GM meal were characterized by higher degrees of proliferation than the negative control. The observed immune response of the remaining examined samples was at the level of negative control. There were no significant $(\mathrm{P}<0.01)$ differences in the immune response to genetically modified and traditional materials. The immune response of lymphocytes isolated from the blood of the examined animals to samples containing allergenic proteins was found to be at the level of negative control or slightly above in the case of $7 \mathrm{~S}$ and $11 \mathrm{~S}$ fractions of the GM meal as well as in the case of 7S fraction of the meal prepared from soybean cv. Nawiko.

Experts' opinions (including domestic research) should be taken into account when planning the future of Polish food and feed production as well as for further formulation of legislation (Twardowski, 2011).

The present study may not show significant results but adds to the debate on the safe use of modified soybean feeds in pig diets.

\section{References}

Armstrong C.L., Mikel W.B., Stan is i ews ki E.P., Hartnell G.F. (2002). Soybean meal from Roundup Ready or conventional soybeans in diets for growing-finishing swine. J. Anim. Sci., 80: 708-715. 
Baranowski A., Ros ochacki S., Parada R., Jaszczak K., Zimny J., Połoszynow i c z J. (2006). The effect of diet containing genetically modified triticale on growth and transgenic DNA fate in selected tissues of mice. Anim. Sci. Pap. Rep., 24: 129-142.

B e r k Z. (1992). Technology of production of edible flours and protein products from soybeans. FAO Agricultural Services Bulletin no. 97, Food and Agriculture Organization of the United Nations, Roma.

B e s l e r M., H e $1 \mathrm{~m}$ R.M., O g a w a T. (2000). Allergen data collection - update: Soybean (Glycine max), Internet Symposium on Food Allergens, 2: 1-35.

Cromwe 11 G.L., Lind e mann M.D., Randolph J.H., Parker G.R., Coffey R.D., Lau re n t K.M., Hill J.E, B re id e n b a ch R.W. (1974). Proteins of soybean seeds. Plant Physiol., 53: $742-746$.

Cromwe 11 G.L., Lin de mann M.D., Randolph J.H., P arker G.R., Coffey R.D., L a u rent K.M., Arm strong C.L., Mikel W.B., S t a n i s i e w s ki E.P., Hartnell G.F. (2002). Soybean meal from Roundup Ready or conventional soybeans in diets for growing-finishing swine. J. Anim. Sci., 80: 708-715.

Holzhauser T., W a c kermann O., B a 11 m e r - W e ber B.K., B in d s l e v - J e n s e n C., S c i bilia J., P e rono-Garoffo L., Uts umi S., P ouls en L.K., V i e th s S. (2009). Soybean (Glycine max) allergy in Europe: Gly $\mathrm{m} 5$ (beta-conglycinin) and Gly $\mathrm{m} 6$ (glycinin) are potential diagnostic markers for severe allergic reactions to soy. J. Allergy Clin. Immunol., 123: 452-458.

J ęd ru se k-Golińs k a A., S z y m andera - B u s zk a K., H ęś M., Z i ę t a r a P. (2010). Knowledge on soybean, its preparations and allergenic properties among students of two universities in Poznań. Hygiea Public Health, 45: 177-180.

L a s z lo J.A. (1988). Content and bioavailability of minerals in soybean hulls. In: L. McCann (Ed.), Proceedings of Symposium on Soybean Utilization Alternatives, Sponsored by The Center for Alternative Crops and Products, US Department of Agriculture, Peoria, Illinois, pp. 333-341.

Liu Ch., W a ng H., Cu i Z., He X., W ang X., Z eng X., M a H. (2007). Optimization of extraction and isolation for $11 \mathrm{~S}$ and $7 \mathrm{~S}$ globulins of soybean seed storage protein. Food Chem., 102: $1310-1316$

N a wr a c a ła J. (2000). Characteristics of soybean mutants obtained after chemical and physical mutagens treatment. Oilseed Crops, 1: 33-46.

Padget te S.R, B iest T.N., Nida D.L., B ailey M.R., Mac Donald J., Holder L.R., F u c h s R.L. (1996). The composition of glyphosate-tolerant soybean seeds is equivalent to that of conventional soybeans. J. Nutr., 126: 702-716.

SAS (1999). SAS User's guide. Statistics version 7th ed., SAS Inst Inc Cary NC.

Song Y.S., Frias J., Martinem-Villaluenga C., Vidal-Valdeverde C. (2008). Immunoreactivity reduction of soybean meal by fermentation. Effect of amino acids composition and antigenicity of commercial soy products. Food Chem., 108: 571-581.

Szymki ewicz A. (2007). Food allergens of plant origin. (In Polish), Przemysł Spożywczy, 7: $35-41$.

Świ ątkiewicz S., Koreleski J. (2008). Genetically modified plants in poultry nutrition. (In Polish). Med. Wet., 64: 1379-1383.

Św i ą tki ew icz S., Św i ą tki ew icz M., Koreleski J., Kw i a tek K. (2010). Nutritional efficiency of genetically modified, insect resistant corn (MON810) and glyphosate tolerant soybean meal (Roundup Ready) for broilers. Bull. Vet. Inst. in Puławy, 54: 43-48.

Świ ątkiewicz M., Hanczakowska E., Twardowska M., Mazur M., Kwiatek K., Kozaczyński W., Św i ąt ki e wi c z S., S i e radzki Z. (2011). Effect of genetically modified feeds on fattening results and transfer of transgenic DNA to swine tissues. Bull. Vet. Inst. Puławy, 55: 121-125

Thanh Vu Huu, Okubo K., Shibas aki K. (1975). Isolation and characterization of the multiple 7S globulins of soybean proteins. Plant Physiol., 56, 19-22.

T s u j i H., K i m o to M., N a t o r i Y. (2001). Allergens in major crops. Nutr. Res., 21: 925-934.

Tw a r d ow s ki T. (2011). Yet GM! (In Polish). Nauka, 1: 99-103.

W r ó b lew s k a B. (2002). Big eight food allergens. (In Polish). Alergia, 4/15 (on line). 
MARIOLA GALBAS, KAMILA BORYS, ANNA WOŹNIAK, MAREK SELWET

\section{Wplyw globulin soi genetycznie modyfikowanej i konwencjonalnej na proliferację limfocytów świńskich w kulturach in vitro}

\section{STRESZCZENIE}

Większość globalnego rynku zdominowała soja transgeniczna Roundup Ready 40-3-2, wprowadzona przez firmę Monsanto, cechująca się tolerancją na glifosat, składnik aktywny herbicydu Roundup. Uprawia się również w niewielkich ilościach soję konwencjonalną. Należy jednak pamiętać, że soja należy do jednego z głównych alergenów, który może mieć wpływ na zdrowotność zwierząt.

Celem pracy było porównanie właściwości alergennych globulin soi modyfikowanej genetycznie i konwencjonalnej wyhodowanej w Polsce. Analizy dokonano mierząc proliferację limfocytów świńskich w kulturach in vitro. Okazało się, iż soja modyfikowana genetycznie oraz konwencjonalna wywołują odpowiedź immunologiczną na poziomie kontroli negatywnej. Nieznaczny wzrost w stosunku do kontroli negatywnej obserwowano w przypadku frakcji 7S i 11S pochodzących ze śruty GM oraz frakcji 7S izolowanej ze śruty Nawiko. 